Vol. 21. No. 1, 85-92 , Mei 2018

DOI: $10.18196 /$ st. 211214

\title{
Perilaku Antarmuka Berdasarkan Data Beda Tekanan pada Peristiwa Kondensasi Aliran Uap Dengan Pendinginan dari Luar Searah pada Pipa Horisontal Berbasis Domain Waktu
}

\author{
(Interface Behavior Based on Differential Pressure Data on Steam Flow Condensation With Outside \\ Direct Cooling at Horizontal Time-Based Domestic Pipes)
}

\author{
SUKAMTA, HASAN ASY ARI DWIEARTO, SUDARJA
}

\begin{abstract}
A two-phase flow pattern experiment on the condensation event of steam flow with external cooling based on the measurement of pressure difference within a horizontal pipe is carried out by varying the superficial velocity. Annulus pipes with inner pipe material made of copper and outer pipe made of galvanized iron (GIP) within an insulation of $10 \mathrm{~mm}$ thick were used in this experiment. The length of the pipe is 1.6 meters, outer diameter of 4 inch and inner diameter of $17 \mathrm{~mm}$. The two-phase flow pattern was investigated based on differential pressure fluctuations between the inlet and outlet. To support the observation, flow pattern visualization was performed using a transparent pipe with a diameter of $3 / 4$ inch and a length of 1.3 meters connected to the test pipe section. The superficial vapor velocity was carried out from JG $=0.0689 \mathrm{~m} / \mathrm{s}$ to $\mathrm{JG}=1,9117 \mathrm{~m} / \mathrm{s}$. The results showed stratified flow patterns for the lowest superficial velocity and also obtained wavy, wavy-slug, and slug. Annular flow patterns can not be observed in this experiment. In general, increasing superficial velocity of steam will cause a significant increase in pressure fluctuations.
\end{abstract}

Keywords: Two-phase flow, condensation, steam-condensate, differential pressure, horizontal pipe.

\section{PENDAHULUAN}

Aliran dua fase adalah bentuk yang paling sederhana dari aliran multifase. Untuk mendeskripsikan aliran ini biasanya digunakan dua komponen yang memiliki substansi kimia berbeda, seperti aliran uap-air atau aliran udaraair. Aliran dua fase dapat dibedakan atas beberapa kategori, seperti fase-fase aliran (gascair, cair-padat, dan padat-gas), arah aliran (searah dan berlawanan arah) dan kedudukan saluran (vertikal, horisontal, atau miring). Aliran dua fase banyak kita jumpai di alam bebas seperti kabut, asap, hujan, mendung, salju, dan lain-lain. Adapun contoh aliran dua fase yang terjadi pada proses industri misalnya pada ketel uap, kondensor, alat penukar panas, reaktor nuklir, pencairan gas alam, pipa saluran, dan lain-lain (Wallis, 1969). Hal yang sangat penting untuk dipelajari dari suatu aliran, baik satu fase maupun dua fase adalah pola aliran. Aliran satu fase memiliki tiga pola aliran utama yaitu laminer, transisi, dan turbulen. Ketika pola aliran berubah dari laminer ke turbulen, di sinilah sifat aliran dari fluida mengalami perubahan yang komplek. Situasi yang komplek tersebut kurang lebih juga terjadi pada aliran dua fase, hanya saja pola aliran pada dua fase lebih beragam. Pola aliran menjadi poin penting dalam studi kasus aliran dua fase, misal pada fase cair-gas. Perilaku campuran antara cair-gas mengandung banyak hubungan yang saling terkait yang diperlukan dalam penyelesaian persamaan konservasi dua fase (two-phase conservation equation), yang ini bergantung pada seberapa jauh identifikasi pola aliran bisa dilakukan. Begitu pula pada kasus aliran air-uap air pada proses kondensasi aliran internal. Aliran dua fase pada kondensasi mempunyai beberapa karakteristik yang berbeda dari umumnya aliran dua fase lainnya. Perpindahan kalor (laju kondensasi) dan hidrodinamika menjadi dua faktor berpasangan yang sangat berpengaruh dan sensitif terjadap pola aliran. Metode untuk memprediksi jarak atau daerah munculnya pola aliran dua fase yang umum terjadi pun menjadi sangat penting untuk dikembangkan, dan sering dibutuhkan, salah satunya dengan menggunakan analisa dan 
permodelan sistem aliran dua fase. Pola aliran merupakan aspek yang sangat menarik sekaligus sulit pada aliran dua fase, dan hal ini telah diteliti selama beberapa dekade hingga sekarang. Metode-metode terkini yang digunakan untuk memprediksi pola aliran masih sangat jauh dari sempurna. Kesulitan dan tantangan muncul pada bentuk pola aliran yang sangat beragam dari setiap fase-fase aliran. Hal ini disebabkan karena banyaknya parameter yang mempengaruhi. Beberapa faktor fisis yang memicu terjadinya variasi pola aliran di antaranya:

a. Perbedaan densitas antar fase, sehingga respon masing-masing fase berbeda-beda terhadap gaya seperti gaya gravitasi dan sentrifugal.

b. Perubahan bentuk pola aliran pada perpindahan fase yang tidak sempurna sehingga terjadi penggabungan aliran yang terus-menerus dan prosesnya sulit diidentifikasi.

c. Gaya tegangan permukaan yang cenderung mempertahankan aliran menyebar satu fase.

Pola aliran dan jarak terjadinya tiap-tiap pola aliran sangat dipengaruhi oleh sifat-sifat fluida, bentuk atau posisi pipa (miring, vertikal, atau horisontal), besar sistem, terjadinya perubahan fase, dan lain-lain (Ghaasiaan, 2008).

Berkaitan dengan pola aliran dua fase, ada beberapa poin penting yang harus diperhatikan:

a. Pola aliran dan kondisi yang memicu transisi pola aliran dipengaruhi oleh geometri sistem dan sifat-sifat cairan. Sifat-sifat yang paling berperan di antaranya tegangan permukaan, kekentalan cairan, dan rasio densitas cairan dan gas. Geometri sistem berkaitan dengan posisi pipa terhadap pengaruh gravitasi, bentuk dan ukuran saluranpipa, aspek rasio (panjang terhadap diameter) dan faktorfaktor lainnya.

b. Pola aliran pokok seperti bubbly, stratified, churn, dan annular-dispersed terjadi pada semua sistem. Detail pola aliran yang terjadi pada masing-masing sistem sangat bergantung pada geometri saluran.

c. Pada kenyataannya, penentuan pola aliran yang dijabarkan pada literatur-literatur tidak sepenuhnya mempresentasikan gambar yang lengkap dari seluruh bentuk pola aliran yang mungkin terjadi. Dengan mempertinggi tingkat kedetailan pola aliran yang komplek atau rumit, sangat mungkin untuk menentukan pola aliran yang lebih halus lagi. Namun, peta pola aliran pokok yang banyak dijelaskan di literatur-literatur telah diterima secara luas sepanjang waktu ini. Batas daerah perubahan pola aliran (regime change boundaries) adalah daerah yang paling sulit untuk diidentifikasi karena terjadi pada daerah transisi yang cukup halus perbedaannya.

d. Pola aliran bubbly, plug/slug, churn, dan annular juga terjadi di minichannels (100 $\mu \mathrm{m} \leq D \leq 1 \mathrm{~mm}$ ).

e. Pada kondisi adiabatik, aliran horisontal, memiliki bentuk pola aliran sederhana yang kemungkinannya bisa diidentifikasi meliputi 4 tipe: stratified (smooth and wavy), intermitten(plug, slug, dan semua pola aliran yang terjadi di antara keduanya), annulardispersed, dan bubbly.

f. Pada saluran adiabatik pola aliran yang terbentuk pada proses boiling (pendidihan) dan kondensasi mempunyai perbedaan yang cukup signifikan (Ghaasiaan, 2008).

Penelitian tentang pola aliran kondensasi pada berbagai sudut kemiringan telah dilakukan oleh Wang dkk dengan menggunakan pipa berdiameter $16 \mathrm{~mm}$ dan panjang $1,2 \mathrm{~m}$ menggunakan fluida kerja refrigerant $\mathrm{R}-11$. Hasilnya, ternyata pola aliran yang paling variatif terjadi pada saluran horisontal (Wang dkk, 1998). Sukamta (2011) telah melakukan penelitian mengenai aliran dua fase pada peristiwa kondensasi uap dalam pipa horisontal dimana penelitiannya dilakukan dengan mengalirkan uap pada pipa kondensor (pipa bagian dalam dari pipa annulus), kemudian didinginkan dengan air pendingin yang mengalir (pada pipa annulus bagian luar). Penelitian tersebut dilakukan dengan mengalirkan uap dan air secara berlawan arah. Berdasarkan uraian di atas, pengkajian terhadap kondensasi aliran dua fase masih sangat luas cakupannya. Banyak ilmu yang masih bisa digali untuk menjelaskan fenomena pola aliran dua fase yang beragam, baik dari sisi geometri, orientasi atau posisi pipa, maupun proses yang terjadi di dalam pipa (boiling, kondensasi, campuran cair-gas, dan sebagainya). Santosa dkk, (2012) pada penelitiannya Pola aliran slug mempunyai ciri khusus dimana aerasi terjadi pada seluruh bagian likuid slug. Selain itu, batas antara kantung dan liquid slug tidak halus. Pola aliran kantung yang diamati ditunjukkan pada Gambar 1. 


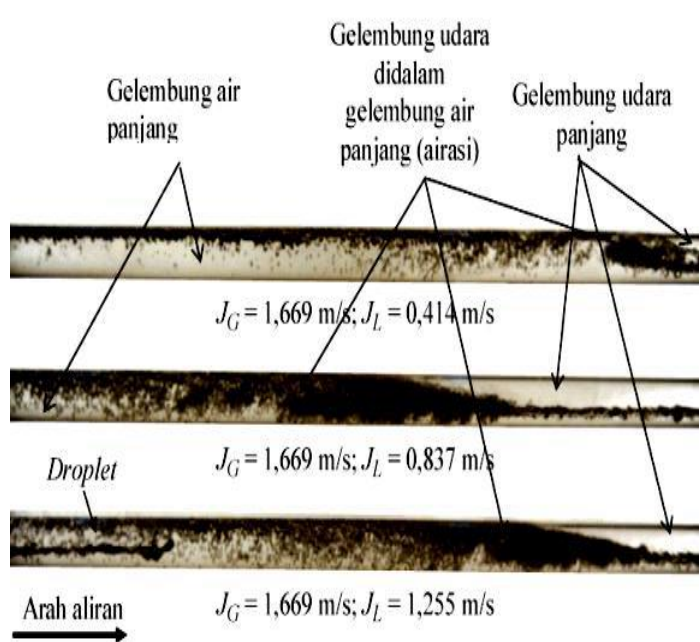

GAMBAR 1. Tipe pola aliran slug hasil observasi penelitian.(Santosa dkk, 2012)

Kemudian, data pola aliran slug yang didapat dibandingkan dengan peta pola aliran Mandhane dkk. (1974) seperti ditunjukkan Gambar 2.

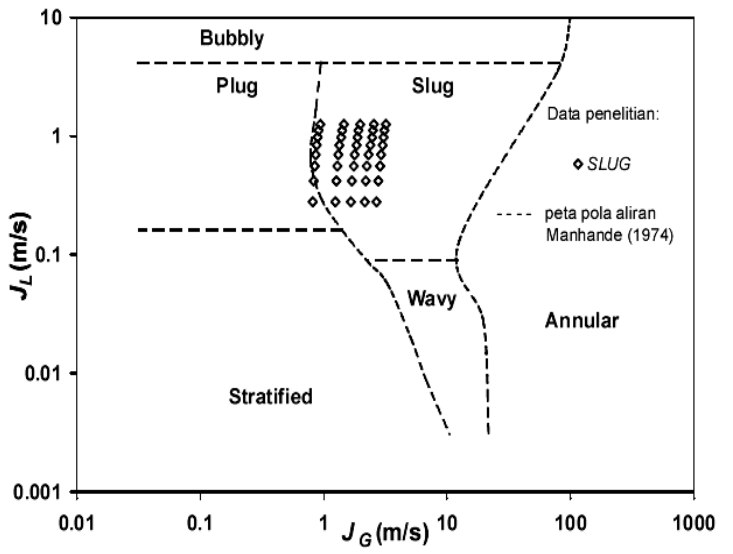

GAMBAR 2. Peta pola aliran (Mandane dkk, 1974)

Gambar 2 mengindikasikan bahwa data pola aliran slug yang didapat adalah sesuai dengan hasil penelitian Mandhane dkk. (1974). Pengukuran beda tekanan sebagai fungsi kecepatan superfisial fluida ditunjukkan pada Gambar 2 dengan rentang kecepatan superfisial udara: $\mathrm{J}_{\mathrm{G}}=0.417-2.504 \mathrm{~m} / \mathrm{s}$ dan rentang kecepatan superfisial air: $\mathrm{J}_{\mathrm{L}}=0.279-1.255 \mathrm{~m} / \mathrm{s}$. Sinyal beda tekanan aliran slug diperlihatkan Gambar 3. Sinyal ini mempunyai harga puncak yang banyak yang disebabkan oleh kecepatan gelembung air yang dimasuki gelembung udara mengalir dengan kecepatan tinggi. Sedangkan diantara rentang harga puncak cenderung bernilai nol yang mengindikasikan adanya aliran gelembung udara. Gambar 3 juga memperlihatkan bahwa kenaikan kecepatan superfisial fluida mengakibatkan kenaikan harga puncak beda tekanan.
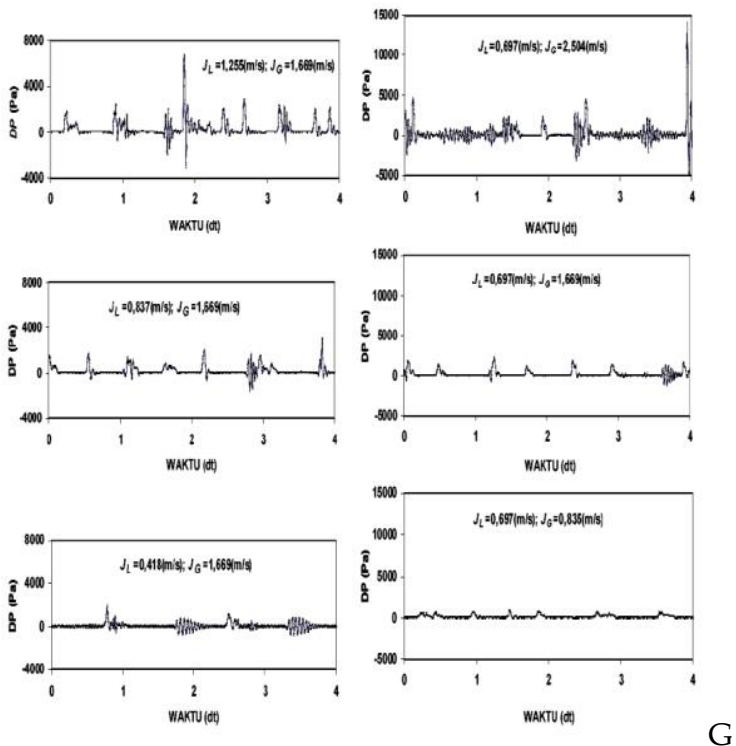

AMBAR 3. Tekanan diferensial dalam rangkaian waktu (Santosa dkk, 2012)

Sukamta (2010) juga telah meneliti grafik gradien tekanan $h_{L}$ di sepanjang pipa horisontal aliran dua fase air-uap air yang dihasilkan dari proses kondensasi disajikan dalam beberapa variasi debit uap. grafik gradien tekanan yang terekam selama kurang lebih 140 detik dan telah diolah dengan menggunakan perangkat lunak Sigview, dipilih beberapa rentang waktunya yang memiliki gradien tekanan mencolok dan kemudian dianalisis dan diintepretasikan. Hasil dari grafik gradien tekanan tersebut kemudian didukung dengan visualisasi hasil perekaman video yang telah diubah menjadi pecahan-pecahan (frame-frame) gambar, sehingga dapat diketahui pola aliran yang terbentuk dan fenomena dominan yang menyebabkan terjadinya gradien tekanan mencolok tersebut. Yang perlu menjadi catatan sebagaimana sudah dijelaskan di depan, bahwa visualisasi yang terjadi pada pipa transparan dan gradien tekanan antara titik inlet dan outlet adalah hasil kumpulan gejala yang terjadi di sepanjang pipa kondensat. Berdasarkan hasil penelitian dan pembahasanyang tersebut di atas, didapatkan kesimpulans bahwa pola aliran yang teridentifikasi pada alirandua fase air-uap air (kondensat) dari hasil kondensasi uap pada pipa horisontal ini meliputi pola aliran stratified, wavy, plug,pre-slug, dan slug.

\section{Metode Penelitian}

Bahan penelitian ini adalah aquades, digunakan sebagai bahan penghasil uap air yang akan dikondensasikan untuk membentuk aliran dua 
fase pada pipa horisontal yang dipanaskan dengan menggunakan boiler, dan air yang digunakan sebagai pendingin pada pipa anulus bagian luar. Alat penelitian (Gambar 4) terdiri atas pipa anulus bagian dalam dari bahan tembaga berdiameter $17 \mathrm{~mm}$ dengan panjang 1,6 m, sedangkan pipa anulus bagian luar adalah pipa besi berdiameter 4 inchi dengan panjang 1,6 m. Pipa kaca dengan diameter 17 $\mathrm{mm}$ dan panjang $1,2 \mathrm{~m}$ digunakan untuk mengetahui visualisasi pola aliran dua fase yang terjadi.

Sensor beda tekanan digunakan untuk mendeteksi gradien tekanan yang terjadi di sepanjang pipa $(\mathrm{L}=1,6 \mathrm{~m})$. Peralatan akuisisi data (data logger) digunakan untuk merekam data yang terbaca oleh sensor tekanan. Akuisisi data ini sudah dilengkapi dengan bahasa pemrograman Delphi 7 dan diatur dengan sampling rate 7.353 data/detik.Validasi sampling rate telah dilakukan dengan memberikan trigger berasal dari generator yang besarannya telah diketahui kebenarannya

kepada peralatan data akuisisi, hasilnya peralatan akuisisi yang digunakan ini valid. Proses kalibrasi terhadap hasil pengukuran beda tekanan oleh data akuisisi dilakukan dengan mengalirkan air ke dalam pipa uji, kemudian dilakukan pengukuran beda tekanan dengan menggunakan peralatan data akuisisi tersebut dan dengan melakukan perhitungan beda tekanan (rugi-rugi mayor) akibat adanya aliran air pada pipa tersebut dengan jarak 1,6 m.

Proses kalibrasi/penyetaraan ini berfungsi untuk mengetahui apakah debit uap yang ditunjukkan oleh tinggi kolom air manometer orifice nilainya tepat atau tidak. Kalibrasi/penyetaraan debit uap menggunakan udara dipilih dengan pertimbangan bahwa persentase error jika uap dianggap gas ideal (udara) pada tekanan gauge keluar uap rata-rata 1,75 atm $\left(\mathrm{P}_{a b s}=2,75 \mathrm{~atm}\right)$ masih dapat ditoleransi, yaitu sekitar 2,65\%.

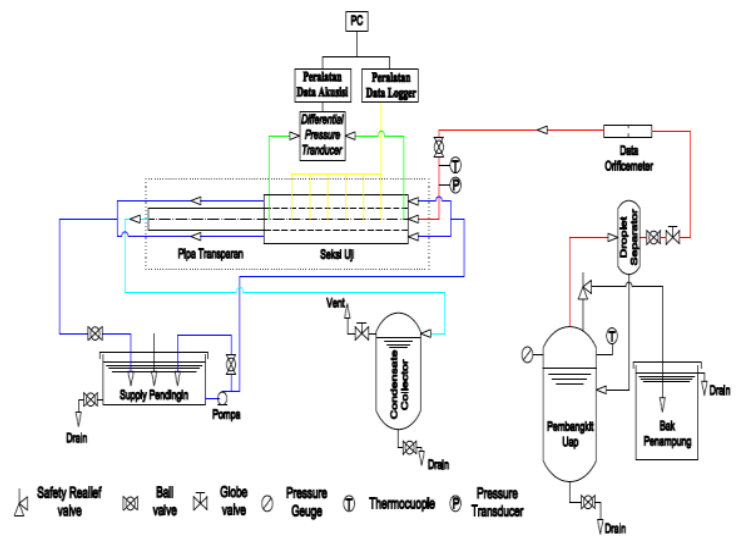

GAMBAR 4. Sekema alat uji

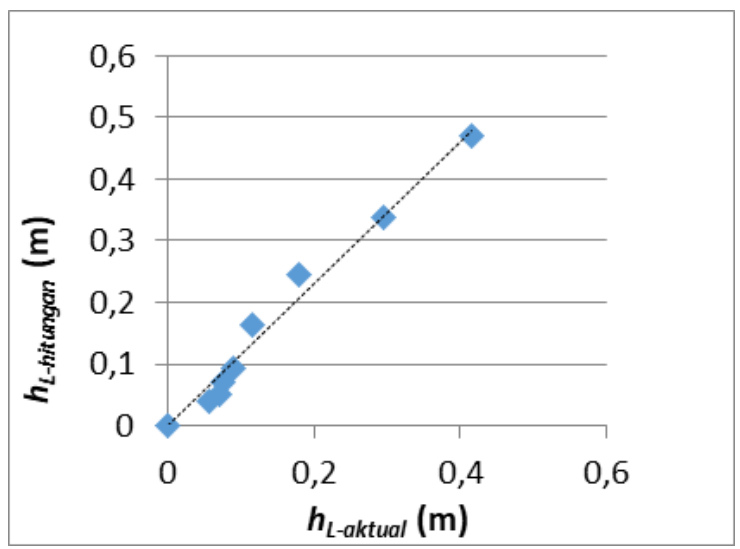

GAMBAR 5. Hubungan antara hL-aktual (m) dengan hL-hitungan 


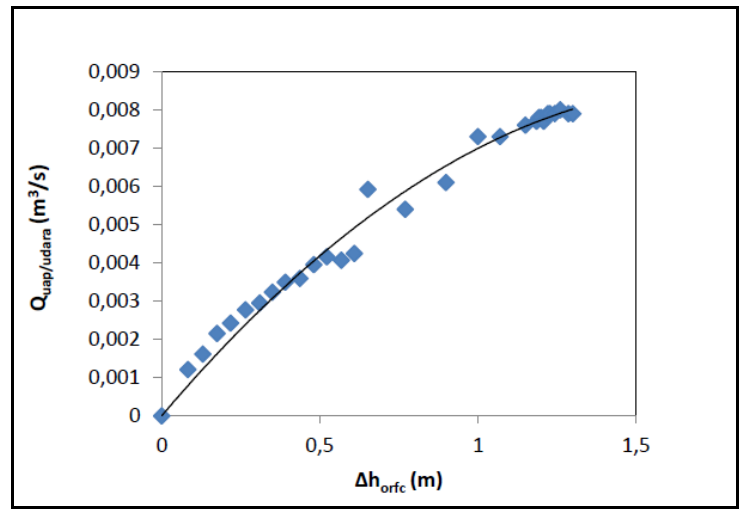

GAMBAR 6. Hubungan debit udara/uap (Quap/udara) dengan beda tekanan orifice ( $\Delta$ horfc)

Dari Gambar 6 dapat dilihat bahwa hubungan antara debit uap/udara $\left(Q_{\text {uap/udara }}\right)$ dengan beda tekanan orifice $\left(\Delta h_{\text {orfc }}\right)$ mempunyai hubungan kuadratis dengan persamaan:

$Q_{\text {uapudara }}=-0,0027 \Delta h_{\text {orfc }}{ }^{2}+0,0097 \Delta h_{\text {orfc }}$

Dengan derajar ketelitian $\mathrm{R}^{2}=0,9838$ atau $98,38 \%$

\section{HASIL DAN PEMBAHASAN}

Hasil penelitian terhadap grafik beda tekanan di sepanjang pipa horisontal aliran dua fase airuap air yang dihasilkan dari proses kondensasi disajikan dalam 6 (enam) variasi kecepatan superfisial uap. Grafik beda tekanan yang terekam selama kurang lebih 1 detik dan telah diolah dengan menggunakan software Sigview. Grafik tersebut kemudian dicocokkan dengan visualisasi hasil perekaman video yang telah di ubah menjadi pecahan-pecahan (frame-frame) gambar sehingga dapat diketahui pola aliran yang terbentuk. Yang perlu menjadi catatan sebagaimana sudah dijelaskan di depan, bahwa visualisasi yang terjadi pada pipa transparan dan beda tekanan antara titik inlet dan outlet adalah hasil kumpulan gejala yang terjadi di sepanjang pipa kondensat. Berikut ini grafik beda tekanan yang dikelompokkan berdasarkan variasi kecepetan superfisial uap yang masuk ke dalam pipa kondensasi:

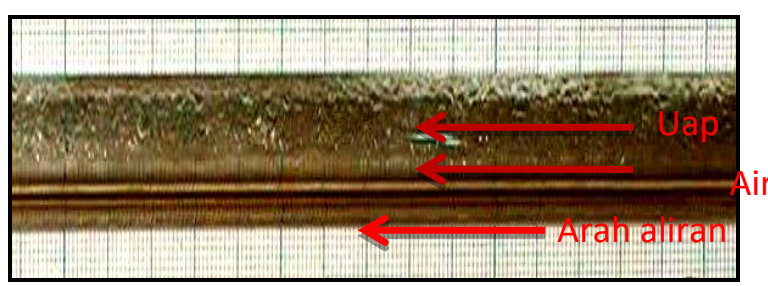

GAMBAR 7. Visualisasi aliran pada $\boldsymbol{i}_{\boldsymbol{G}}=0,0689 \mathrm{~m} / \mathrm{s}$

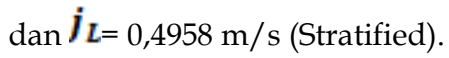

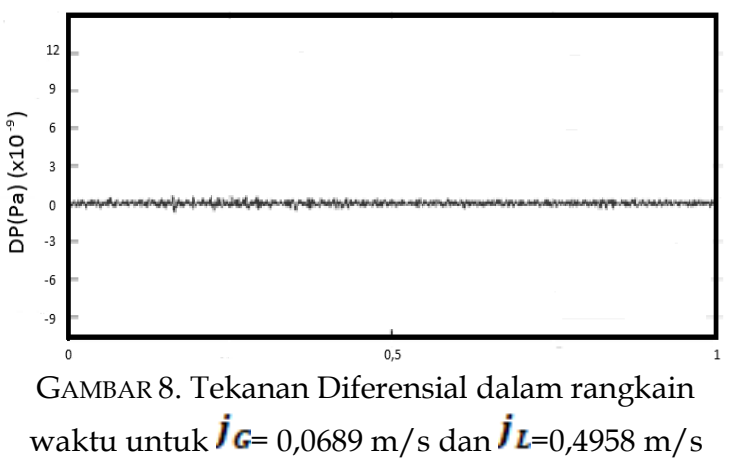

Hubungan penjalaran beda tekanan terhadap waktu di dalam pipa uji untuk kecepatan superfisial uap $\boldsymbol{j}_{\boldsymbol{G}}=\mathbf{0 , 0 6 8 9} \mathrm{m} / \mathrm{s}$ dan $\mathrm{kec}$. superfisial air $\boldsymbol{j}_{\boldsymbol{L}}=\mathbf{0}, \mathbf{4 9 5 8} \mathrm{m} / \mathbf{s}$ ditunjukkan pada Gambar 8 dijelaskan bahwa beda tekanan ratarata bernilai konstan tetapi berfluktuasi kecil ditunjukkan dengan grafik berbentuk garis lurus horisontal dengan rentang harga beda tekanan yang berharga nol namun berombak kecil atau berfluktuasi kecil dan diperkuat dengan gambar 7 visualisasi pola aliran berbentuk stratified, cairan kondensat di bagian bawah membentuk lapisan yang teratur dengan ketebalan tertentu. Jika aliran ini diganggu dengan gelombang tertentu, maka terjadi gangguan pula pada lapis batas muka (antar muka) sehingga beda tekanan juga mengalami fluktuasi dengan besaran tertentu. Adanya fluktuasi menunjukkan terjadinya passing wave. Semakin berfluktuasi menunjukkan bahwa jumlah passing wave semakin banyak.

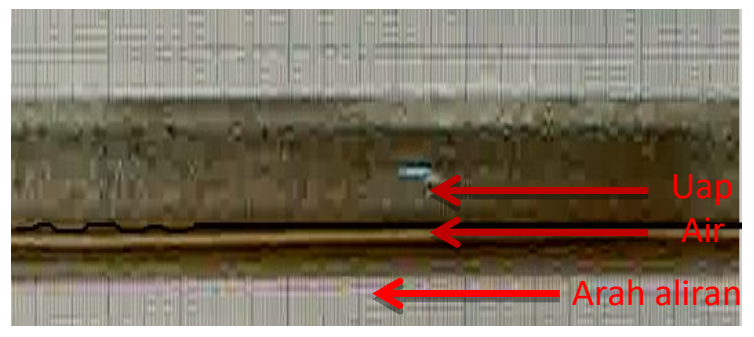

GAMBAR 9. Visualisasi aliran pada $\boldsymbol{i}_{\boldsymbol{G}}=0,1405 \mathrm{~m} / \mathrm{s}$ dan $\boldsymbol{i}_{\boldsymbol{L}}=0,4958 \mathrm{~m} / \mathrm{s}$ (Stratifed-wavy)

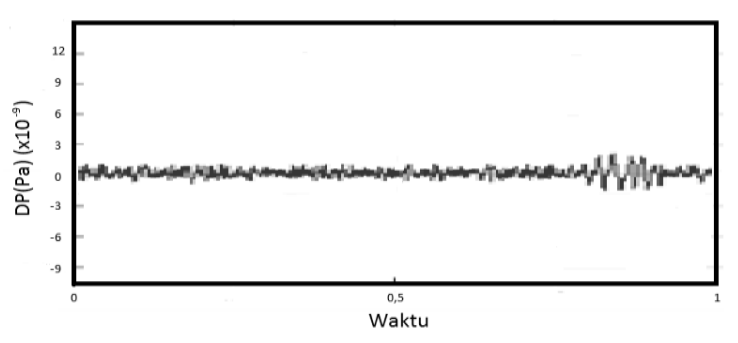

GAMBAR 10. Tekanan Diferensial dalam rangkain waktu untuk $\hat{\boldsymbol{j}}_{\boldsymbol{G}}=0,1405 \mathrm{~m} / \mathrm{s}$ dan $\boldsymbol{j}_{\boldsymbol{L}=0,4958 \mathrm{~m} / \mathrm{s}}$ 
Selanjutnya, analisis tersebut digunakan untuk menginterpretasikan grafik pada percobaan selanjutnya. Dari Gambar 10 dapat dijelaskan bahwa rentang harga beda tekanan berharga nol dan berfluktuasi kecil tetapi sedikit lebih tinggi jika dibandingkan pada Gambar 9, itu karena ditingkatkannya kec. superfisial uap menjadi $\boldsymbol{j}_{G}=\mathbf{0 , 1 4 0 5} \mathrm{m} / \mathbf{s}$. Berdasarkan data ini dapat diinterpretasikan bahwa aliran yang terbentuk adalah stratified-wavy. Analisis ini diperkuat dengan visualisasi pola aliran berbentuk stratified-wavy seperti ditunjukkan pada Gambar 10.

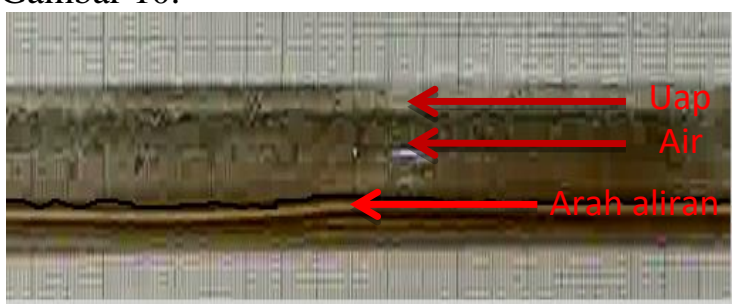

GAMBAR 11. Visualisasi aliran pada $\boldsymbol{j}_{\boldsymbol{G}}=0,1620 \mathrm{~m} / \mathrm{s}$

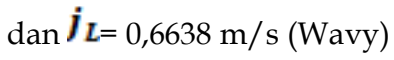

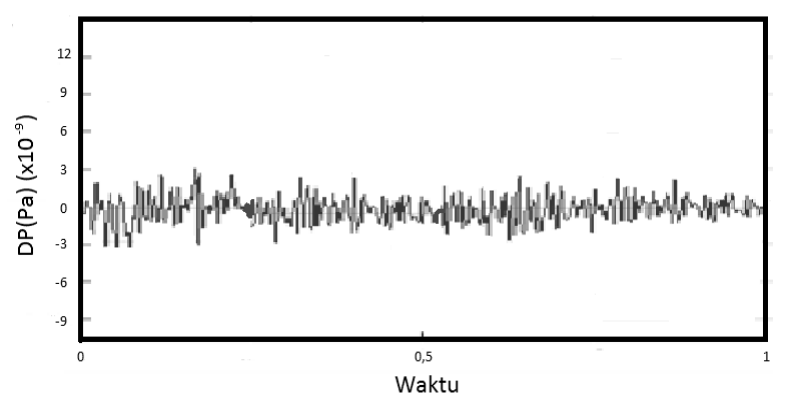

GAMBAR 12. Tekanan Diferensial dalam rangkain

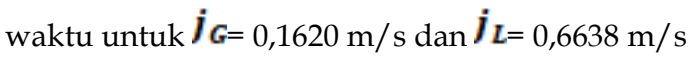

Namun, jika kecepatan superfisial uap ditingkatkan menjadi $\boldsymbol{j}_{G=} \mathbf{0 , 1 6 2 0 ~} \mathbf{m} / \mathbf{s}$, sementara kecepatan superfisial aliranair pendingin $\boldsymbol{j}_{L}=$ $\mathbf{0 , 6 6 3 8 ~} \mathbf{m} / \mathbf{s}$, pada Gambar 12 terjadi fluktuasi beda tekanan yang memiliki rentang harga beda tekanan mulai melebihi harga nol, yang berarti telah mulai terjadi gangguan di dalam aliran dua fase tersebut karena adanya efek Bernoulli.Namun efek ini masih relatif kecil, seperti dilihat pada fluktuasi beda tekanannya.

Dari kedua data ini maka dapat diinterpretasikan bahwa pola aliran yang sedang terjadi adalah wavy, didukung dengan visualisasi pola aliran berbentuk wavy yang terjadi pada Gambar 11.Pola aliran wavy ini belum mampu menyebabkan terjadinya vaporlocked atau slugging, tetapi berpotensi menyebabkan vapor-locked atau slugging.

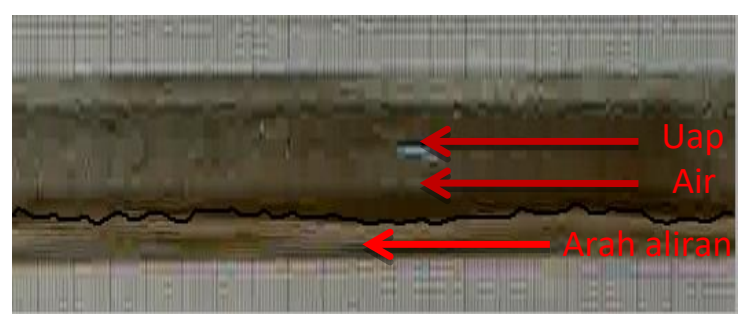

GAMBAR 13. Visualisasi aliran pada $\hat{j}_{\boldsymbol{G}}=0,5934 \mathrm{~m} / \mathrm{s}$

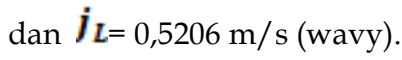

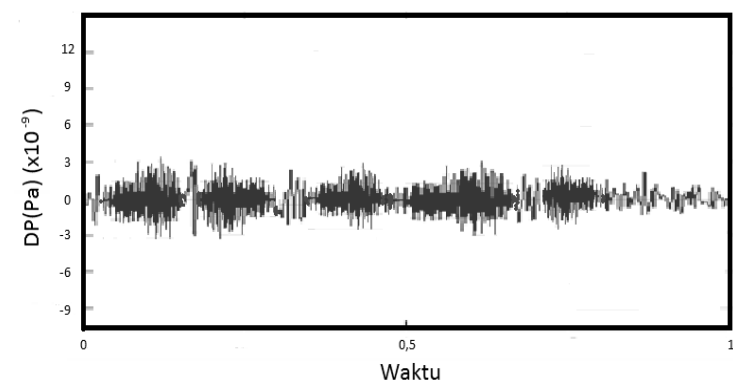

GAMBAR 14. Tekanan Diferensial dalam rangkain waktu untuk $\boldsymbol{j}_{\boldsymbol{G}}=0,5934 \mathrm{~m} / \mathrm{s}$ dan $\boldsymbol{f}_{\boldsymbol{L}=0,5206 \mathrm{~m} / \mathrm{s}}$

Jika aliran kecepatan superfisial uap dan air ditingkatkanyaitu $\boldsymbol{j}_{G=} \quad \mathbf{0 , 5 9 3 4} \quad \mathrm{m} / \mathrm{sdan} \hat{j}_{L}=$ $0,5206 \mathrm{~m} / \mathrm{s}$, maka nampak fluktuasi beda tekanan seperti ditunjukkan pada Gambar 14. Dari gambar tersebut dapat diketahui bahwa beda tekanan berfluktuasi dengan sedang, hampir sama seperti fluktuasi pada grafik sebelumnya namun yang ini sedikit lebih tinggi dan rentang harga beda tekanannya melebihi nol yang menunjukkan telah terjadi condensate passing wave dengan jumlah yang sedang pula. Adanya condensate passing wave ini menunjukkan ada penambahan aliran masa kondensat di pipa uji dengan jumlah yang sedang. Dari data ini dapat dinterpretasikan bahwa kondensat mengalir dengan bergelombang sedang yang disebut dengan pola aliran wavy.Pola aliran wavy ini masih belum mampu menyebabkan vaporlocked, tetapi berpotensi terjadi slugging dan water hammer seperti ditunjukkan pada Gambar 13.

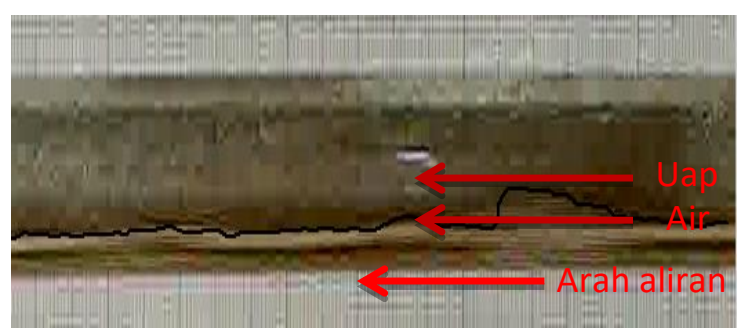

GAMBAR 15. Visualisasi aliran pada $\hat{\boldsymbol{J}}_{\boldsymbol{G}}=0,8917 \mathrm{~m} / \mathrm{s}$

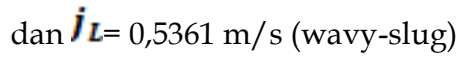




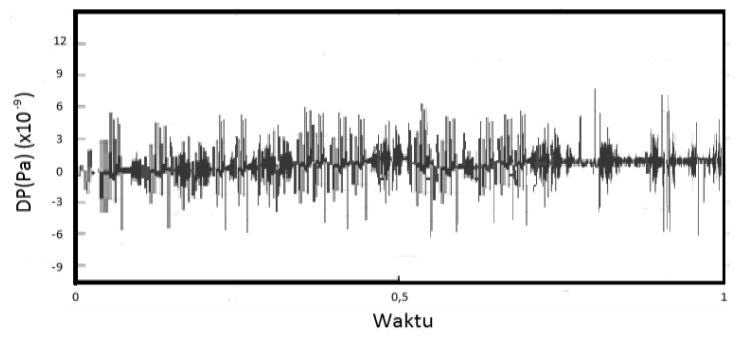

GAMBAR 16. Tekanan Diferensial dalam rangkain waktu untuk $\boldsymbol{j}_{\boldsymbol{G}}=0,8917 \mathrm{~m} / \mathrm{s}$ dan $\boldsymbol{J}_{\boldsymbol{L}}=0,5361 \mathrm{~m} / \mathrm{s}$

Jika aliran kecepatan superficial uap dan air ditingkatkan yaitu $\hat{j}_{G=} \mathbf{0 , 8 9 1 7} \mathrm{m} / \mathrm{s}$ dan $\hat{\boldsymbol{j}}_{L}=\mathbf{0 , 5 3 6 1}$ $\mathbf{m} / \mathbf{s}$, maka Nampak fluktuasi beda tekanan seperti ditunjukkan pada gambar 16. Dari gambar tersebut dapat diketahui bahwa beda tekanan berfluktuasi dengan sedang, hampir sama seperti fluktuasi pada grafik sebelumnya namun yang ini sedikit lebih tinggi dan rentang harga beda tekanannya melebihi nol yang menunjukkan telah terjadi condensate passing wave dengan jumlah yang sedang pula. Adanya condensate passing wave ini menunjukkan ada penambahan aliran masa kondensat di pipa uji dengan jumlah yang sedang. Dari data ini dapat dinterpretasikan bahwa kondensat mengalir dengan bergelombang sedang yang disebut dengan pola aliran wavy-slug.Pola aliran wavyslug ini berpotensi mampu menyebabkan vapor-locked, sehingga pada aliran ini dimungkinkan terjadi slugging dan water hammer seperti ditunjukkan pada gambar 15 ..

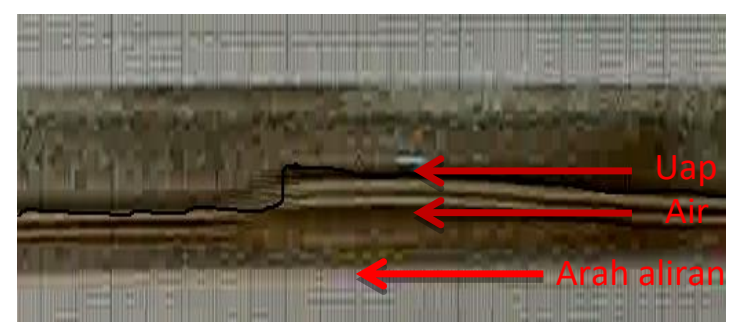

GAMBAR 17. Visualisasi aliran pada $\hat{\boldsymbol{V}}_{\boldsymbol{G}}=1,9117 \mathrm{~m} / \mathrm{s}$

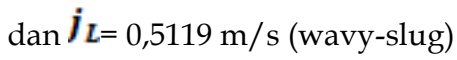

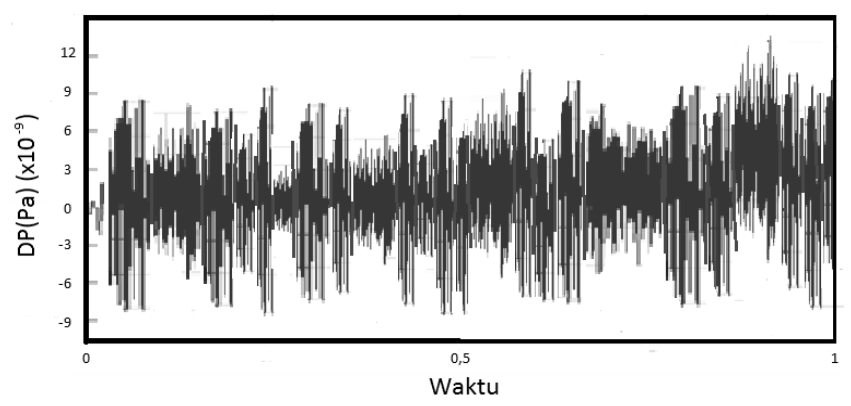

GAMBAR 18. Tekanan Diferensial dalam rangkain

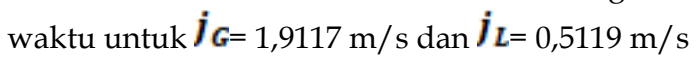

Pada saat kec. Superfisial uap ditingkatkan dengan signifikan menjadi $\hat{j}_{\boldsymbol{G}} \mathbf{1 , 9 1 1 7} \mathrm{m} / \mathrm{s}$ maka Nampak fluktuasi beda tekanan yang cukup signifikan seperti ditunjukkan pada Gambar 18. berdasarkan visualisasi aliran pada Gambar 17, dapat digambarkan bahwa jumlah passing wave yang terbentuk semakin tinggi dan semakin sering (banyak) lagi. Ini menunjukkan bahwa jumlah massa yang lewat juga semakin meningkat. Dengan semakin meningkatnya massa kondensat yang lewat ini maka kondensat semakin menumpuk pada bagian bawah da nmembentuk ketebalan tertentu. Selanjutnya kondensat ini terdorong oleh aliran steam, maka terjadilah aliran wavy yang lebih besar disbanding pada Gambar sebelumnya, sehingga lebih tepat kalau disebut wavy-slug. Dapat dilihat hal ini menunjukkan bahwa jumlah massa kondensat yang melewati pipa semakin besar dan terdorong oleh uap sehingga terbentuklah aliran wavy yang cukup besar sehingga dinamakan wavy-slug, dimaksudkan untuk menggambarkan bahwa pola alirannya adalah wavy yang mendekati slug. Pola aliran slug inilah yang merupakan inisiasi terjadinya water hammer. Hasil Penelitian ini sesuai dengan Sukamta (2010). Sementara itu, Santosa (2012) juga melakukan pengukuran beda tekanan sebagai fungsi kecepatan superfisial fluida dengan rentang kecepatan superfisial udara: $\mathrm{J}_{\mathrm{G}}=0.417-2.504 \mathrm{~m} / \mathrm{s}$ dan rentang kecepatan superfisial air: $\mathrm{J}_{\mathrm{L}}=0.279-1.255 \mathrm{~m} / \mathrm{s}$. Hasilnya, bahwa kenaikan kecepatan superfisial fluida mengakibatkan kenaikan harga puncak beda tekanan. Kenaikan kecepatan superfisial air memperpendek rentang harga beda tekanan yang berharga nol, sebaliknya kenaikan kecepatan superfisial udara memperpanjang rentang harga beda tekanan yang berharga nol.

\section{KESIMPULAN}

Berdasarkan hasil penelitian dan pembahasan yang telah dilakukan pada bab sebelumnya, didapatkan kesimpulan sebagai berikut:

1. Pola aliran yang teridentifikasi pada aliran dua fase air-uap air dari hasil kondensasi uap pada pipa horisontal ini meliputi pola aliran:

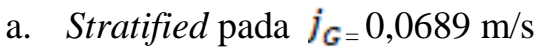

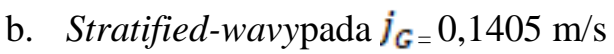
c. Wavy pada $j_{G}=0,1620 \mathrm{~m} / \mathrm{s}$ dan $j_{G}=$ $0,5934 \mathrm{~m} / \mathrm{s}$




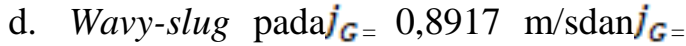
$1,9117 \mathrm{~m} / \mathrm{s}$

e. Tidak ditemukan pola aliran bubbly dan annular pada penelitian ini

f. Tidak terjadi aliran slug tetapi ditemukan wavy-slug yang mampu menyebabkan terjadinya slugging

2. Dari sinyal grafik data beda tekanan berdasarkan variasi kecepatan superfisial uap diketahui bahwa semakin tinggi kecepatan superfisial uap dengan laju air pendingin (cooling water) yang dianggap tetap dikarenakan variasi pendingin memiliki rentang yang hampir sama tiap variasinya, fluktuasi sinyal beda tekanan di sepanjang pipa kondensat juga semakin meningkat secara umum.

\section{DAFTAR PUSTAKA}

Budi Santoso, dkk, 2012, Fluktuasi Beda Tekanan dari Pola Aliran Slug Air-Udara pada Aliran Dua Fase Searah Pipa Horisontal, Jurnal Teknik Mesin ROTASI

Cengel, Y.A. dan Boles, M.A., 1994, Thermodynamics an Engineering Approach, $2^{\text {nd }}$ edition, Mc Graw-Hill Inc, USA.

Djojodiharjo, H., 1994, Dasar-dasar Termodinamika Teknik, PT Gramedia, Jakarta.

Ghiaasiaan, S.M., 2008, Two Phase Flow, Boiling, and Condensation in Conventional and Miniatur System, Cambridge University Press, Cambridge.

Kakac, S. dan Mayinger, F., 1976, Two Phase Flows and Heat Transfer, volume1, Hemisphere Publishing Corporation, Washington dan London.

Kirsner, W., 1999, Condensation Induce Waterhammer, HPAC Heating/Piping/Air Conditioning.
Sukamta, dkk, 2010, Identifikasi Pola Aliran Dua Fase Uap-Kondensat Berdasarkan Pengukuran Beda Tekanan pada Pipa Horisontal, Jurnal Ilmiah Semesta Teknika

Sularso dan Tahara, H., 2006, Pompa dan Kompresor, Pemilihan, Pemakaian, dan Pemeliharaan, PT Pradnya Paramita, Jakarta.

Triatmodjo, B., 1996, Hidraulika I, Beta Offset, Yogyakarta

Wallis, G.B., 1969, One Dimensional Twophase Flow, McGraw-Hill, USA.

Wang, dkk., 1998, Two-phase Flow Patterns and Transition Characteristics for Intube Condensation with Different Surface Inclinations, International Journal of Heat and Mass Transfer.

PENULIS:

Sukamta

Prodi Teknik Mesin, Fakultas Teknik, Universitas Muhammadiyah Yogyakarta, Yogyakarta.

Email:msukamta@gmail.com

Hasan Asy Ari Dwiearto

Prodi Teknik Mesin, Fakultas Teknik, Universitas Muhammadiyah Yogyakarta, Yogyakarta.

Email: hasan.asy.2011@ft.umy.ac.id

Sudarja

Prodi Teknik Mesin, Fakultas Teknik, Universitas Muhammadiyah Yogyakarta, Yogyakarta.

Email: sudarja_msn@yahoo.com 